\title{
Performance of nurses/nursing team in the dispensing of materials for users of home care services
}

\author{
Performance do enfermeiro/equipe de enfermagem na dispensação \\ de materiais para assistência ao usuário no domicílio \\ Performance del enfermero/equipo de enfermería en la dispensación \\ de materiales para asistencia al usuario en el domicilio
}

\section{Priscila de Carvalho Freitas ${ }^{\mathrm{a}}$ Daniel Magno Galdino ${ }^{a}$ Maria de Fátima Grillob Carmen Lucia Mottin Duro ${ }^{a}$ Êrica Rosalba Mallmann Duarte ${ }^{a}$ Dagmar Elaine Kaiser ${ }^{a}$}

How to cite this article: Freitas PC, Galdino DM, Grillo MF, Duro CLM, Duarte ERM, Kaiser DE. Performance of nurses/nursing team in the dispensing of materials for users of home care services. Rev Gaúcha Enferm. 2020;41(esp):e20190151. doi: https://doi.org/10.1590/19831447.2020.20190151
Universidade Federal do Rio Grande do Sul (UFRGS). Escola de Enfermagem. Porto Alegre, Rio Grande do Sul, Brasil.

- Hospital de Clínicas de Porto Alegre (HCPA) Unidade Básica de Saúde Santa Cecillia. Porto Alegre, Rio Grande do Sul, Brasil.

\section{ABSTRACT}

Objective: To contextualize the performance of nurses/nursing team in the dispensing of materials to assist users in home visits, in primary care.

Methods: Dialectical qualitative study conducted between March and April 2018 in which 24 nurses from primary health care units in the Gloria/Cruzeiro/Cristal District of Porto Alegre, Rio Grande do Sul, completed the self-administered questionnaire, whose data were treated by thematic content analysis. The study was approved by the Research Ethics Committee.

Results: Two categories emerged from the empirical corpus: logistic chain of material management for home user assistance; production of services and capacity of the team.

Conclusion: The work processes related to materials management for home user assistance and the resulting health services production require a look at specificities such as workload and technologies involved, as they move the performance of the nurse/ nursing staff.

Keywords: Nursing. Primary health care. Organization and administration. Community health services. Health resources.

\section{RESUMO}

Objetivo: Contextualizar a performance do enfermeiro/equipe de enfermagem na dispensação de materiais para assistência ao usuário no domicílio, na atenção básica.

Métodos: estudo qualitativo dialético. Entre março e abril de 2018, 24 enfermeiros de unidades de saúde da atenção básica do Distrito Gloria/Cruzeiro/Cristal, de Porto Alegre, Rio Grande do Sul, responderam ao questionário autoadministrado, cujos dados foram tratados mediante Análise de Conteúdo Temática. 0 estudo foi aprovado por Comitê de Ética em Pesquisa.

Resultados: Do corpus empírico resultaram duas categorias: cadeia logística do gerenciamento de materiais para assistência ao usuário no domicílio; produção de serviços e a capacidade da equipe.

Conclusão: Os processos de trabalho referentes ao gerenciamento de materiais para assistência ao usuário no domicílio e a produção de serviços em saúde decorrentes requerem um olhar para especificidades como carga de trabalho e tecnologias envolvidas, por moverem a performance do enfermeiro/equipe de enfermagem.

Palavras-chave: Enfermagem. Atenção primária à saúde. Organização e administração. Serviços de saúde comunitária. Recursos em saúde.

\section{RESUMEN}

Objetivo: Contextualizar el desempeño del enfermero/equipo de enfermería en la dispensación de materiales para asistencia al usuario en el domicilio, en la atención básica.

Métodos: Estudio dialéctico cualitativo. Entre marzo y abril de 2018, 24 enfermeros de unidades de salud del Distrito Gloria/Cruzeiro/ Cristal, Porto Alegre, Rio Grande do Sul, respondieron al cuestionario autoadministrado, cuyos datos fueron tratados mediante Análisis de Contenido Temático. El estudio fue aprobado por el Comité de Ética en Investigación.

Resultados: Del corpus empirico resultaron dos categorías: cadena logística de la gestión de materiales para asistencia al usuario en el domicilio; la producción de servicios y la capacidad del equipo.

Conclusión: Los procesos de trabajo relacionados con la gestión de materiales para la asistencia al usuario doméstico y la producción de servicios de salud resultantes requieren un análisis de las especificidades carga de trabajo y tecnologías involucradas, a medida que mueven el desempeño de la enfermería/enfermería.

Palabras clave: Enfermería. Atención primaria de salud. Organización y administración. Servicios de salud comunitaria. Recursos en salud. 


\section{口INTRODUCTION}

The demand for improvements in health quality, in primary care, has encouraged innovative strategies and practices. Therefore, nurses must be aware of the care standards and work processes that are legally assigned to them ${ }^{(1)}$. Thus, the development of managerial activities by nurses requires a proactive and innovative conduct regarding the services produced by the nursing team, planning actions that involve the decision-making process, conflicts, nursing workforce, permanent health education, organization of inputs and materials ${ }^{(2)}$.

In 2011, the Ministry of Health created the Programa Melhor em Casa - PMC (Better at Home program), a home care program through which users, according to their clinical needs, had access to home care provided by a multidisciplinary team, with the mobilization of new technological arrangements in routine health care, by stimulating home care. In addition to allowing users to complete the treatment at home, shortening the length of hospital stay, the program also provided for the free distribution of medications and supplies necessary for the management of home care users ${ }^{(3)}$. Healthcare regulations focused on the needs of home care users and PMC-related work processes posed challenges and required spending from the different government levels.

In 2015, the Municipal Health Department of Porto Alegre (SMS-POA) introduced a computerized inventory management system with the implementation of the Materials Management system (GMAT). This system allowed the implementation of the single registry of materials and its supply, speeding up the management of stocks and storerooms $s^{(4)}$.

The Technical Note No. 01/2017 (NT-01/17) ${ }^{(5)}$ was issued by the General Coordination of Primary Care and the Municipal Institute of Family Health Strategy (IMESF), from SMS-POA in 2017 in Porto Alegre, state of Rio Grande do Sul. The note includes local regulations concerning care to users with health needs covered by the Basic Health Units (BHU) of primary care (AB), who have difficulty or physical impossibility to access the referred health facilities, and stipulated the dispensing of home care materials to users who need permanent care and resources.

NT-01/17(5), the first document to address the subject, contains detailed information on the materials and quantities provided according to the users'needs and the procedures required, within Primary Care's network of interrelationships where nurses go through several steps to assist users of home care services, in order to ensure the success of the health work process. It is noteworthy that although NT-01/17 $7^{(5)}$ standards have been issued by local management bodies, they apply to regional, national and international health contexts.

Thus, nurses can make decisions regarding the systematization of work processes inherent to materials management and the production of health services, considering organizational and care aspects, in order to meet the common objectives of NT-01/17(5), with the establishment of flows and the definition of strategies for their operationalization. Nurses are then supposed to develop individualized care plans to guide the nursing staff in the delivery of care, in order to meet the users' health needs at home. The purpose is to ensure the recovery of the user and/or the stabilization of his/her health status, which includes the availability of materials to be dispensed in home care to users, reconciling dispensing of materials and production of home care services $^{(5)}$. By ensuring the conditions required for the delivery of appropriate home care services to users these plans also shape the performance desired for both the nurses and the nursing staff, for the sake of quality care and to meet the new health care practices established by NT-01/17(5-6).

A historical review about the concept of performance reveals that this term has been used as a synonym for performance in management, in an attempt to measure the efficiency and achievement of the objectives of health professionals and services ${ }^{(7)}$.

Thus, nurses/nursing staff should have characteristics such as ability to analyze the work processes established by NT-01/17(5), initiative to implement health actions, interpersonal relationship and communication skills in their interactions with health teams or users/ families, ability to work in a team and leadership in user care. These characteristics highlight their knowledge, skills and attitudes concerning the competencies of their profession, and should be reflective, collaborative and analytical for health action ${ }^{(3)}$, providing details about the performance of nurses/nursing team regarding the production of services, the comprehensiveness of care and the guarantee of continuous home care to users.

Thus, nurses should use their accumulated competencies and adjust them in order to meet the care flows of NT-01/17(5), applying them to the work processes involved in the planning, organization and systematization of actions and control of the resources required ${ }^{(1)}$.

By producing services and health, nurses accumulate technical knowledge and expertise in the organization of nursing work processes ${ }^{(1,8)}$. So they are prepared to deal with unpredictability, in unexpected situations or in the search for care that vary in diversity and complexity, by managing care and solving problems that may arise in their routine, and deal with the existing problems related to the implementation of public policies ${ }^{(9)}$. 
In accordance with NT-01/17 $7^{(5)}$, the materials required for home care users should be prescribed by physicians, or nurses in a nursing consultation, as part of the request for materials of the UBS. The nursing staff forwards monthly UBS requests for supplies to the Municipal Health Department (SMS). If, on the one hand, the presence of large stocks of some materials in the institution is a concern for nurses in the management of materials, on the other hand, shortage of these supplies may result in discontinuity of care, leading to harmful and stressful experiences to users and communities users, as well as to the professionals and teams involved in health care.

This mobilizes nurses/nursing staff to create the necessary conditions for the appropriate use of the materials obtained, according to the opportunities and fundamentals of NT-01/1 $7^{(5)}$, so as to decisively intervene in the health outcomes of home users. By combining knowledge and professionalism with the management activities of dispensing materials for users of home care services, nurses also perform care activities.

Regarding these considerations, it is necessary that nurses/nursing staff are aware of the different types of knowledge required to meet the objectives of NT-01/17(5), establishing relationships of interdependence between need for care to users of home care services, materials management at the UBS and Primary Care purposes, shaping the desired nursing performance.

In view of the above considerations, and given the scarcity of Brazilian studies on materials management in primary care, the following question can be posed: How does the nurse/nursing team manage materials for users of home care services in primary care?

In order to answer this question and understand the dynamics of material management practices, the present study aimed to contextualize the performance of nurses/ nursing staff in the dispensing of materials for home care in primary care.

\section{DETHODOLOGY}

Dialectical qualitative study, which addresses an approximate interpretation of reality, where the impact of reason and experience on the study object are apprehended through reciprocal and dialectically integrated relations. From a historical point of view, dialectical logic recognizes social phenomena as outcomes and effects of creative activity, and its center of analysis is social practice, human action. This creative activity is perceived as a result of synergies between internal and external developments, and also as a praxis ${ }^{(10)}$.
Based on this idea, the present study attempts to answer very particular questions, concerned with a degree of reality that cannot be quantified, valuing meanings, aspirations, motives, values, attitudes and beliefs about the performance of nurses/nursing team in the dispensing of materials, in primary care, for home care users, which involves deeper relations, processes and phenomena that cannot be reduced to the operationalization of variables, Thus, the study provided understanding and visibility, exposing subtle distinctions and responding to very particular concerns of this performance.

The study was carried out at the 25 UBSs of the Gloria, Cruzeiro and Cristal District Management (GD-GCC) of the Municipal Health Department of Porto Alegre, in two different scenarios: a service organized with Family Health Strategy (eESF) teams and another service organized according to the most traditional Primary Care (AB) model, with Primary Care (eAB) teams, where nurses are responsible for the coordination of health units and the production of services that rely on the UBS territory (area) as the core strategy, and its main objectives are the delivery of comprehensive, continuous, effective and high quality care, focused on the health needs of the population.

The eESF consists of at least one physician, preferably specialized in family and community medicine; one nurse, preferably a family health specialist; one nurse assistant and/or technician and community health agents. Endemic diseases control agents and oral health professionals may integrate the team: dental surgeon, preferably a family health specialist, and an oral health aide or technician. To ensure care management, access and effectiveness of eESF teams, it is recommended that the population covered ranges from 2,000 to 3,500 people, in order to comply with Primary Care principles and guidelines ${ }^{(11)}$.

In turn, the Primary Care (AB) team must meet the principles and guidelines proposed for primary care, according to the characteristics and needs of the municipality. The minimum team consists of physicians, preferably family and community medicine specialists; nurses, preferably family health specialists; nurse assistants and or nurse technicians. Other professionals such as dentists, oral health aides and/ or oral health technicians, community health workers and endemic diseases control agents may be added. Since the priority model is the ESF (family health strategy), Primary Care teams (eABs) may eventually be organized according to the priority model(11).

The nurses were invited to participate in the study during a meeting of the Gloria, Cruzeiro and Cristal District Management (GD-GCC), where the research project was explained to the teams and for the purpose of data collection. The 
inclusion criterion was nurses who have been working in municipal primary care for more than one year. The exclusion criterion was health professionals who, despite their wish to participate in the stud, had some conditions that could impair the research or even produce an unwanted bias to the results. Thus, 24 nurses were eligible to participate in the study and all of them worked in materials management. Only one nurse did not participate in the study, as this professional believed he/she could not make any contribution to the study because he/she was not involved in materials management in the UBS.

In order to explore the participants' ideas and experiences regarding the theme, data collection was guided by a Self-administered Questionnaire (SAQ) $)^{(10)}$ that explored the participants' sociodemographic profile and the concerns of the study based on the stipulations of NT-01/17(5). The questionnaire contained five open-ended questions related to the contextualization of the performance of nurses/ nursing team in the dispensing of materials for home care users: How do you manage nursing activities related to the dispensing of materials for users of home care services in primary care? How is the type, quantity and need for materials for care to users of home care services? What difficulties do you identify with your team when dispensing materials to provide home care to users? What potential (s) do you identify with your team when dispensing materials for home care users?

The SAQ was made available online and at the UBSs for completion between March and April 2018. Participants took approximately 30 minutes to complete the questionnaire, and 24 completed questionnaires were returned. In the qualitative records, the nurses described their thoughts and the way in which they managed materials, particularly the dispensing of materials for home care to users and the care provided.

A critical analytical process of data was used through thematic analysis ${ }^{(10)}$, reading of the completed questionnaires, ordering and classification of information through the reading of the transcripts and constitution of an empirical corpus. Some standards of qualitative validity ${ }^{(12)}$ were considered, such as exhaustiveness and relevance and, finally, the inflection point between the empirical material from the questionnaires, and the theoretical material, in a ceaseless dialectical movement from the concrete to the abstract, from the particular to the general, from the theoretical basis of the National Primary Care Policy ${ }^{(11)}$ to
NT-01/17(5), in order to obtain contributions based on the statements (excerpts) of the nurses that participated in the study. And the interpretation of these statements, in addition to overcoming the dichotomy objectivity versus subjectivity, exteriority versus interiority, analysis and synthesis, was a moment of praxis for the researcher, revealing secrets of their own conditioning to the performance of the nurses/ nursing staff in the dispensing of materials for users of home care services, in primary care, and allowing relationships, contradictions and connections to be established from the subcategories.

Thus, thematic analysis resulted in two thematic categories: logistic chain of the management of materials dispensed for the care of users of home care services and staff capacity.

Regarding the ethical aspects involved in the study, the recommendations contained in resolutions 466/2012 and 510/2016 of the National Health Council, which set out the guidelines and regulatory standards for research involving human subjects, were followed. The study is part of the project: "Integrated Research on Work Organization and Comprehensive Health Services: New technologies in the care of users with skin wounds in the Health Care Network of the State of Rio Grande do Sul" approved by the Research Ethics Committee of Federal University of Rio Grande do Sul (EP/UFRGS) CAAE: 56382316.2.0000.5347, and the Research Ethics Committee of the Municipal Health Department of Porto Alegre, under protocol no 1.737.204, of September 21, 2016, CAAE 56382316.2.3001.5338.

After agreeing to complete the SAQ, each participant signed the Informed Consent Form (TCLE) in two copies. To preserve the anonymity of the study participants, the participants chose codes composed of letters and numbers, as follows: N1, N2, N3 [...] N24.

\section{RESULTS AND DISCUSSION}

Twenty-four (24) nurses, most of them female (19), with ages ranging from 26 to 41 years and who have been working in Basic Health Units (UBS) for 1 to 16 years participated in the present study.

Chart 1 shows the analytical synthesis of the empirical corpus of responses to SAQ regarding the performance of nurses/nursing staff in dispensing materials for home care users, in primary care, in accordance with the aforementioned NT-01/17 (5). 


\begin{tabular}{|l|l|}
\hline Thematic Categories & Subcategories \\
\hline \multirow{3}{*}{ Logistic chain for the management of the dispensing } & - Assessment/Registration \\
of materials for users of home care services & - Forecast \\
& - Request \\
& - Material receipt and checking \\
& - Minimum stock level/ safety \\
& - Record \\
\hline Production of services and staff capacity & - Nursing consultation \\
& - Home visit \\
& - Educational activities \\
& - Permanent health education \\
& - Collaborative work in care networks \\
& - Teamwork \\
\hline
\end{tabular}

Chart 1 - Thematic categories and thematic subcategories Source: Research data, 2018

These results are discussed below.

\section{- Logistic chain of the management of the dispensing of materials for users of home care services-The nurses} reported that they play a key role in the management of the materials of the UBSs in which they perform their work activities, explaining that they participate in the work processes from the forecast to the final destination of the materials used in the production of services in primary care, as follows:

Home care materials are ordered on a monthly basis, along with other orders of the health unit. (N12)

The nurses routinely predicted the need for the materials dispensed, in order to ensure the conditions required for the development of appropriate care to the users ${ }^{(9)}$. The forecast is facilitated because it includes the number of procedures required and stipulated by nurses during nursing consultation, and the inputs to be dispensed to the users are previously defined, such as materials for healing chronic injuries, nasoenteral, gastric, bladder, parenteral tubes, among other items. This was one of the main concerns expressed by participants concerning the forecast of materials, not only for compliance with the provisions of NT-01/17 (5). This forecast of material resources, which is necessary to meet the unpredictability of care demands of the users covered by the UBS, is the most difficult forecast performed by nurses:

We do not know how many procedures we will have to perform. We also don't know how many dressings will be performed on a given day. Of course, we know the number of registered users who receive materials for home care use. This is easy to predict. However, some users are told in the emergency room or hospital to go to the UBS to receive care, and this cannot be predicted. (N16)

Management and logistics can be complicated, because some materials may be missing. (E18)

The assessment of the amount of materials to be requested by nurses at the UBS is determined by the consumption profile, with the establishment of a fraction of the materials that represents an estimate of how much will be spent or what will to be used over a given period. Forecasting is part of inventory control and is an important action of material management to determine the quantity of each item that is required because the UBS has the history of home care users.

My orders are placed via GMAT [...]. (N2)

After the home visit the material is requested through the GMAT (N5)

I write down the user's needs in the bill of special materials and then request the items needed from GMAT. (N18)

With the implementation of the computerized inventory management system at the Municipal Health Department of Porto Alegre (SMS-POA), through GMAT (Materials Management system), nurses obtained access to the single registry of materials and its provision ${ }^{(4)}$. However, the respondents said they were very cautious when ordering materials at GMAT, checking the materials available at the unit to 
determine whether there was a real need for requesting materials for the delivery of their services and providing information on the consumption of materials at the UBS, to avoid making mistakes:

I request the materials according to the check made by the nurse technicians. I ask them to make this check (N2)

Whenever we place a monthly order, we count the materials in the unit to avoid requesting more items than necessary or forgetting to order items that are needed. (N16)

Ordering materials without prior checking may lead to the receipt of materials in a quantity other than the required quantity, which may generate peripheral stocks or even deplete the UBS from the supply of materials needed for healthcare. If the quantity of materials delivered by the storeroom is less than the requested quantity, larger quantities of materials will tend to be ordered in subsequent orders to compensate for partially fulfilled previous orders.

When materials arrive at the storeroom of the UBS, they are properly sorted and organized for delivery to users, with checking by list, purchase order, or commitment notice.

When the materials arrive, the nursing staff checks them and leaves them in the storeroom of the unit. (N11)

When the materials arrive at the UBS, they are sorted and organized: some will be kept in the unit and some will be destined home care users (N2)

As soon as the material is received, it is sorted. Kits are organized with the material of each registered user, and the material is identified with each user's name. (N17)

Then, the dispensing of materials for home care users is performed. This activity is performed by the nurse/ nursing team so that the right material is sent to the right user, at the right time and in the right quantities, observing the best conditions for the organization. The work processes are performed through planning, control, organization and other actions related to the flow of materials and information, inside and outside the units, similar to what happens with the materials of the UBS ${ }^{(13-14)}$.

Primary care nurses are responsible, among other things, for dispensing materials for users of home care services. These professionals order special materials, printed materials and equipment according to the users' needs, and are also responsible for receiving these materials when they arrive at the UBS. Then, the quantities received are checked and recorded in the appropriate forms ${ }^{(1)}$.
The nursing staff plays a key role in the organization of materials in accordance with NT-01/17(5), contacting the user/family member to deliver the materials upon receipt at the UBS, and dispensing is made in a nursing consultation office or in the user's home:

Hospital users generally arrive in the unit with a discharge form accompanied by a relative [...]. (N15)

The material is available to the user or relative on a monthly basis, in the second half of the month. The delivery of the material is recorded. (N11)

We inform the users' relatives of the arrival of the materials at the unit. When the users are unable to pick the materials at the UBS, community health agents deliver the items at their homes. (N6)

Thus, the dispensing of materials is facilitated so that home care users have access to them, in their different care spaces, and nurses can request the materials during the monthly order of the UBS. For new users, if they go to the UBS outside the period stipulated for the order, materials available in the stock of the unit are provided ${ }^{(5)}$. In this regard, the use of minimum stock level for the safety of materials in the UBS is suggested.

NT-01/17 $7^{(5)}$ stipulates that a stock of materials not used by home care users (transferred from their homes, or due to death or hospitalization) is used, if necessary, by other individuals who request the materials outside the monthly period stipulated for orders. Thus, material dispensing and inventory control are key aspects of material management at the Basic Health Units. Safety stock ${ }^{(14)}$ is an additional quantity of items to ensure the continuous delivery of services to the users in case consumption is greater than planned, orders are delayed, or else not delivered by the storeroom. One nurse made the following comment in this regard:

We manage the materials in an organized manner, and I am responsible for what is ordered and consumed. We strive to keep the inventory organized and with updated count. So, we rarely have losses due to expired items. Also, we keep only a minimum inventory to maintain the operations of the unit. (N14)

Critical thinking about inventory control is essential to meet the stipulations of NT-01/17 on care and management flow, such as rational use and waste prevention by both professionals and users, in order to guide the correct use of these materials and meet work demands ${ }^{(5)}$. 
There is a hidden concern among nurses regarding the shortage of materials at the UBS and the waiting time for the replacement of an item, when delivery problems occur:

Our requests are always made according to the amount of material needed for consumption by the UBS and for dispensing to users' care at home, but items are always missing! To mitigate this situation, the items received are equally distributed among the users, and some items are kept in the unit. (N10)

The list of materials provided by the Municipal Health Department is limited, and so is the availability of these items. The quantities delivered are sometimes insufficient to meet the needs of users and the UBS. (N14)

Inputs for users who have specific dressing needs, such as pressure injuries, but who cannot afford to buy them, are missing. Sometimes even low cost materials, such as urinary catheters are missing, but the staff can always manage to meet this demand (N11)

Nurses face several challenges in materials management:

The situation is more complicated when there is a shortage of materials in the storeroom of the Health Department. (N3)

We make a monthly inventory control, and nothing can be missing! We also hope that there is no shortage of materials for delivery. (N4)

When we do not receive the items to be handed to the users, we have a problem. (N21)

We do not always have all the inputs, and there are limitations on more suitable materials. (E23)

NT-01/17 $7^{(5)}$ stipulates that users must be informed on the lack of inputs in the UBS, in case there is lack of materials or delay in delivery. UBS users and staff want the right material/item, in proper conditions for use, delivered to the right place, in a timely manner. If there is lack of material, it is of utmost importance that this fact is communicated to users in a timely manner.

Regarding the quality of some materials, one nurse made the following comment:

We have already received adhesive tapes or micropores that do not offer good adhesion, which means that much more than was needed and was intended is spent. (N14)

Replenishment due to material rejection or lack of supplies in the storeroom varies according to the purchasing system of the SMS. In the public health system, procurement occurs through government tenders, and the purchasing process takes 4 to 6 months. In the so-called "pregão" (a lower-priced type of bidding), the items are delivered within one month, ensuring the supply. Respondents said that nurses from different units help each other in these situations.

If the material required is not available in the inventory, nurses are supposed to report this situation to the GD-GCC Technical Nursing Officer for the necessary procedures ${ }^{(3)}$. In an attempt to address user demands and lack of inputs at the UBS, nurses/nursing staff contact other GD-GCC units to address the demand by borrowing or exchanging materials:

Despite the current difficulties faced by the health sector, with lack of investments in material resources, the nursing team can always manage this demand. We contact other nursing teams, and if they have the items that we need in their stock, they provide us with these items in the required quantity. We also maintain frequent contact with the referral center [skin group] for more specific materials e.g. special wound covers. (N11)

NT-01/17 $7^{(5)}$ clearly states that nurses/nursing staff should avoid excess inventory in the unit. Also, in accordance with $\mathrm{NT}-01 / 17^{(5)}$, the ordering of materials intended for users should be standardized in the UBS. The materials are generally distributed according to quotas defined for given periods of time, daily or weekly for UBS, and monthly for users. Thus, at the time of dispensing, it is necessary to verify the quantity, in the presence of a user's relative. Also, nursing or medical prescriptions valid for 120 days, as well as the signature of the user (or a relative) certifying the receipt of the materials/ supplies are requested at this moment. This can be seen in the following statements:

The supplies can be picked by the users in the second half of the month. As soon as the materials arrive at the unit, the team sorts them according to the user, and any nursing professional can deliver them to the users. The delivery of materials is recorded in the stock record book. (N11)

As soon as the materials arrive, we prepare the kits for delivery, and the user and/or relative come to pick them up, signing the receipt on the form. (N5)

NT-01/17 ${ }^{(5)}$ requires the nurses to write off the inventory of materials dispensed, whether these materials are used at the UBS or delivered to the user for home care, informing the quantities received, according to the list of materials per procedure. Nurses must also record users'assessments in the 
citizens'electronic medical record in the forms for evaluation and dispensing of special materials, and send them quarterly to GD's Technical Nursing Officer for follow-up. Different types of forms were used, as follows:

Book and electronic medical record (N12)

Forms (N15, N21)

Electronic spreadsheet (N12)

Printed spreadsheet (N1, N5, N7, N8, N10, N14, N17, N19, N23)

Book (N13)

List of supplies (N18)

No records are made (N4, N16, N20)

Regarding the completion of NT-01/17(5), the nurses interviewed did not always use the three control forms. Respondents E2, E3, E9, E11, E22 and E24 did not mention the registration, an important step in the management of materials, indicating the dissimilarity of the results obtained.

Figure 1 summarizes the logistic chain of the management of material dispensing according to Technical Note 01/2017, in a flow of work process steps that can be replicated in other health care scenarios.

Service production and staff capacity - The results obtained show not only the implication of nurses/nursing teams with materials management in $U B S^{(5)}$ units, but also the involvement of these professionals with the users' health needs, use of resources in service production and staff capacity. Thus, nursing professionals are organized according to the theoretical framework of e-SUS AB, aligned with the proposed restructuring of the Health Information Systems of the Ministry of Health, recognizing that an effective information management results in high quality services to the population ${ }^{(13)}$. The respondents confirmed the importance of the assessment of users' needs in the logistics of the management of materials for the dispensing of inputs to home care users, self-care practices and the guidance of nursing teams in the actions to be performed, reaffirming that clinical management of these users and their registration is performed according to NT-01/1 $7^{(5)}$.

The Nursing Process ${ }^{(15)}$ provides guidance for nurses in the completion of the "Special Materials Needs Assessment Form" with information on the UBS, benefitted users, professional assessment, re-evaluations with the respective dates and conclusions/conducts. In this regard, the respondents stressed the importance of the assessment, as it provides guidance on care:

When I perform the assessment at the user's home I have a better understanding of the user's status and real needs. (N6)

The assessment is an important step in the Nursing Process, as it allows considering the unique care needs and the care inputs that are necessary. It requires skills such as critical thinking, intervention and analysis, ethical decision that makes use of leadership tools in the setting of priorities ${ }^{(15)}$, given the complexity of the care provided to home care users.

NT-01/17(5) recommends that both the need for home care materials and the users' health status must be continuously assessed. Thus, nursing consultation is a strategy, through which care is established in a relationship with the other, strengthening nurse/user bond, and the nurse is supposed to implement the best practices and provide proper care to that specific user. ${ }^{(16)}$.

I usually assess the user during a home visit. Only after this visit the material is requested via GMAT. (N5)

I conduct a home visit to identify the necessary materials, only after this visit I request the material. These are periodic home visits every 6 months to reassess the needs. But this is not always possible. I can only make visits when we have sufficient human resources. (N7)

Sometimes the lack of professionals makes it impossible for nurses to perform home visits:
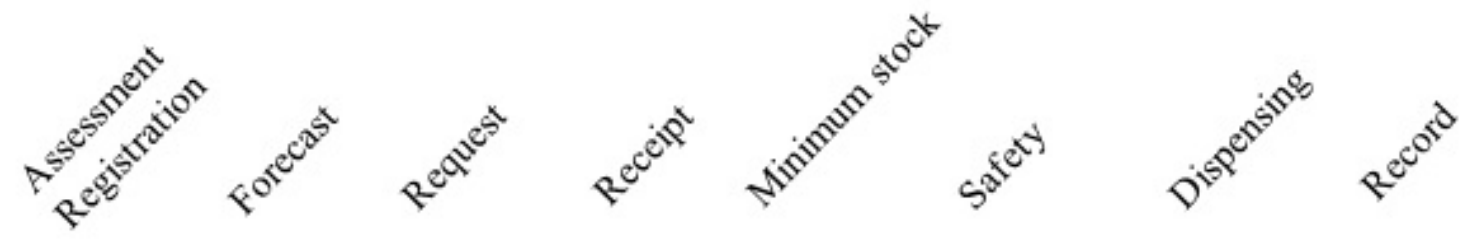

Figure 1 - Logistic chain of the management of materials for users of home care services, according to NT01/17. Source: Research data, 2018. 
[...] We make arrangements, and a professional, a nurse or a nurse technician, makes a home visit to check if the user really needs those materials. Or else, if he/she needs other materials [...]. (N11)

Nurses incorporate cultural and health knowledge into the assessment and therapeutic management of users. The performance of nurses, who in primary care are responsible for coordinating teams that perform their activities in the UBS headquarters and in the area covered by the unit, responds to the growing health needs of people and their lack of access to services provided by a well-distributed and trained workforce, according to the health care needs ${ }^{(15)}$. The educational activities planned for the users/families should be carried out by nurses /nursing staff at home or at the UBS, promoting the social and cultural context, preserving autonomy and encouraging users to feel able to overcome adversity ${ }^{(17)}$.

Whenever I get in touch with the user, I clarify his/her doubts and inform him/her of the personal and effective care to be taken. (N8)

It should be stressed that nurses' engagement in the work dynamics of primary care presupposes knowledge to deliberate on the standardization of materials per procedure and the quantities required to meet the users' real needs $^{(5)}$, with clinical findings and therapeutic interventions that justify the proper receipt of the materials. However:

Sometimes, despite all the meetings held to discuss the subject, we do not proceed in a standard way, which is bad, as it can lead to waste and lack of materials in the unit. (N15)

According to the nurses, Permanent Health Education (EPS) should be aligned with the development of educational proposals, (re) signifying the work process of dispensing materials for home care, a routine situation that is a source of knowledge, reflection and problematization in care practice ${ }^{(18)}$ : Since one of the foundations of home care is deinstitutionalization, it is necessary to monitor the users' recovery from illness in the comfort of their homes.

Thus, nurses/ nursing team collaborate with each other in care networks, through a work that is interdependent on multidisciplinary knowledge and established by continuous professional relationships, involving different actors to provide a more effective care ${ }^{(19)}$.

Examples of referral between points of care of the network in the district management were presented. After a detailed assessment, the nurse requests the necessary material at the GMAT, and the user can pick at the UBS the material to be used in home care.

There have been cases in which the user had been previously examined at a specialist wound care service, and therefore had the indication of the material needed. I can also request this expert assessment and based on this assessment, the material is requested. (E24)

Knowing the population covered by the UBS is a key element in the elimination of care based merely on supply and the establishment of care targeted to the needs of each individual user and based on the possibilities of care in the area covered by the UBS. This allows setting priorities and making referrals in the health care network. This knowledge includes alliances to be able to receive users, or refer them to other centers depending on the disease, comorbidities, risks, management, with access to services, inputs and support resources ${ }^{(20)}$.

Medical prescriptions and discharge forms must be submitted in the registration of users or in the renewal of the dispensing of materials to home care users:

Users referred from another health service must always submit the prescription of materials (N11)

The discharge form details the materials needed for home care. (N24)

Users' relatives generally go to the UBS with the request for materials for medical care contained in the medical prescription. (N7)

Teamwork is the basis for the implementation of comprehensive health actions, and in the present study, particularly, nurses'actions promoted bonding, respect, communication, trust, recognition of others' work and collaboration between professionals and users, as follows:

Nurse technicians and community health agents are very important in this process, as they provide us with information about the users. (N13)

The health team acts in an integrated manner regarding materials dispensing. (N15)

Thus, according to NT-01/17(5) nurses/nursing staff must ensure proper communication, mutual respect and acceptance of differences. These relationships are based on cooperation and exchange between the health areas, on the 
coordination between knowledge and practice, and on joint decisions where the other is perceived as someone with potentialities, promoting autonomy and stimulating the exercise of citizenship ${ }^{(20)}$. Some statements follow:

The assessment of users who receive these special materials should be performed every two months. However, due to the high demand for care in the UBS, this periodicity is not met. (N1)

I centralized the entire material dispensing process on one nurse technician! I need to keep a minimum staff here at the unit (N24)

Some of the difficulties exposed, related to time, organization and pace of tasks, bring to light the overload of nurses/ nursing staff, who, in addition to providing health services, also have managerial demands. Instead of performing activities related to the professional development of nursing, nurse technicians are responsible for administrative activities in the health unit, performing institutional actions to the detriment of care. NT-01/17 highlights the importance of the assessment of users for adjusting or suspending the delivery of materials for home care. Nurse understaffing prevents nurses from performing this assessment at the UBS:

Work overload makes it difficult to monitor the users more frequently through home visits. (N2)

There is lack of human resources. (N5, N6, N7, N8, N10, N12, N20)

Our team is understaffed and thus we cannot meet the work demands (N9)

To ensure that the workforce meets the requirements of NT-01/17(5), it is necessary to reflect on the specificities of workload, technology and primary care:

Sometimes I can't do all my work, I need more time to devote myself more appropriately to this process, but given the lack of human resources, I try to do my best. (N4)

When a nurse says that he/she has not enough time to perform his/her duties, this should serve as a warning! The percentage of nursing staff should be adjusted to the population covered by the UBS ${ }^{(11)}$, taking into consideration the amount of work performed in the unit, technical safety and the working hours of the professionals involved in the work processes, as well as the needs for health interventions, access to the UBS, or even the individuals who receive home care.
Time constraints, inadequate staffing and the accumulation of administrative routines prevent the nurses from achieving the desired performance:

Monitoring users in home care is difficult. Even if they are not assessed on a daily basis, it takes time perform this activity and we also have to make the home visits. I need to make arrangements for the home visits, but I don't always have adequate staffing. (N13)

In primary care, there must be an effective association between services and workforce to ensure safety and high quality care for users ${ }^{(5)}$. Effective implementation of NT-01/17 at the municipal level is suggested, and it is recommended that the interrelationships between nursing workload, services and Primary Care receive more attention from SMS-P and healthcare companies.

Figure 2 shows a synthesis of the results of this study regarding nurses' performance in the dispensing of materials for users of home care services, with important observations about the performance of nurses/nursing staff in their routines, including knowledge and accumulation of ideas of the respondents themselves regarding the work processes recommended in NT-01/17(5)

\section{口 FINAL CONSIDERATIONS}

Although Technical Note No. 01/2017 contemplates a set of collective actions and proposals for the dispensing of materials for home care users, it should be stressed that much of its effectiveness depends on the performance of nursing professionals, who are supposed to understand the care standards and work processes that have been legally assigned to them.

Thus, based on the contributions made by the respondents, the findings of the present study provided insight into management and care issues that produced practical results, although the contradictions and work dynamics of the nurses'routine overloaded the understaffed nursing team.

In some scenarios of primary care, nurses had to perform their activities in work environments that lacked the latest technological resources, and were responsible for the implementation of work processes to meet the requirements of Technical Note No. 01/2017, despite their understaffed nursing teams.

By adopting a critical perspective on nursing practices in the scope of Technical Note No. 01/2017, in primary care, the respondents identified gaps in the organizational and care aspects, reporting that they often could not meet the 


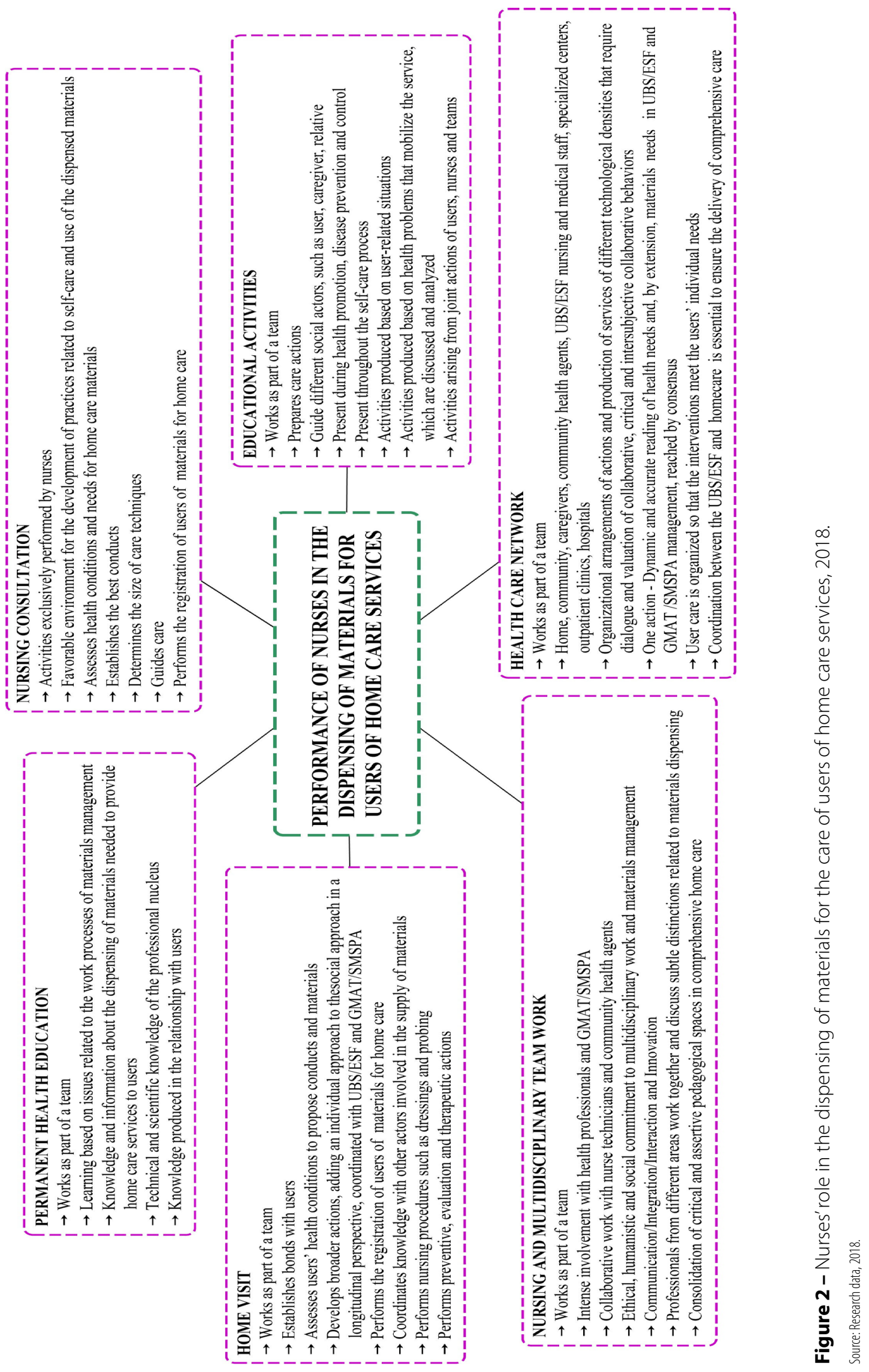


recommendations. In this regard, they reported that joint efforts in initiatives taken by the nursing teams themselves ensured compliance with Technical Note 01/2017, despite work overload, understaffed nursing team and lack of time, meeting the routine work demands through the joint work of the nursing team.

It should be emphasized that the lack of professionals to meet health work demands, the excessive demands of primary care and the intense production of health services in daily life, reported by the nurses, reflect the precariousness of health and the disruption of the model established by Technical Note. 01/2017. Thus, the technical safety of the nursing workforce in health interventions must be reconsidered, and a healthy work environment should be provided to health professionals. The solution to be adopted may empower users of home care services who would have greater autonomy in primary care and the delivery of comprehensive, continuous, resolute and effective care, targeted to the health needs of the population covered.

Moreover, the involvement of nurses with the scientific activities of the study, by completing the self-administered questionnaire, brought knowledge, expertise and visibility to the details that configured their performance and the performance of nursing teams regarding compliance with Technical Note 01/2017. These professionals detailed the specificities of a still little known routine, adding value to the learning process and provoking critical thinking on the need for a qualified practice oriented towards the establishment of effective conducts. This knowledge may support public policies and decision-making by nurses/nursing staff not only in primary care, although NT-01/17 standards were established by a local health department, because these standards are applicable to other regional, national and international health contexts. Therefore, these are contributions to teaching, research, care and management, with re-significations for the funding of the nursing workforce and for health work in primary care, so that the performance of nurses/nursing team effectively and successfully dispense materials for the care of users of home care services.

One limitation of this study concerns its scenario, which consists of health units located in a given primary health care district, characterized by a peculiar technical and organizational support and by nursing and health professionals responsible for the dispensing of materials for home care users. Other healthcare scenarios could also be analyzed, due to their peculiarities regarding materials management and the production of services for home care users.

Thus, further studies on this topic are suggested, as there are many more publications on nurses'views about this topic in the hospital environment than in the different scenarios of primary care in Brazil, which however deserve the same attention. Studies on the ways in which nursing workers allocate their time and arrange to meet managerial and clinical demands in primary care, including home care in the area covered by the UBS and the management of materials, are also needed.

\section{DEFERENCES}

1. Silva RNA, Lima AKM, Carvalho Filha FSS, Vilanova JA, Silva FL. Conhecimento e entendimento de enfermeiros sobre as ações gerenciais na atenção primária à saúde. Ciênc Saúde. 2016;9(1):21-9. doi: https://doi.org/10.15448/1983652x.2016.1.21028

2. Castilho V, Mira VL, Leite MMJ. Gerenciamento de recursos materiais. In: Kurgant $P$, coordenador. Gerenciamento em enfermagem. Rio de Janeiro: Gauanabara Koogan; 2016. p. $145-57$.

3. Ministério da Saúde (BR). Secretaria de Atenção à Saúde. Departamento de Atenção Básica. Caderno de atenção domiciliar. Brasília: Ministério da Saúde; 2012.

4. Prefeitura de Porto Alegre [Internet]. Porto Alegre; (2015-2019 [cited 2018 May 1]. Saúde capacita servidores para informatização dos almoxarifados; [approx. 1 screen]. Available from: http://www2.portoalegre.rs.gov.br/portal_pmpa_ cidadao/default.php?p_noticia=179197

5. Prefeitura Municipal de Porto Alegre (BR). Secretaria Municipal de Saúde. Coordenadoria Geral da Atenção Básica, Instituto Municipal de Estratégia de Saúde da Família. Nota Técnica 01/2017: Dispõe sobre 0 atendimento a idosos domiciliados em ILPI pelas unidades de saúde da atenção básica. Porto Alegre; 2017.

6. Oliveira NC, Chaves LDP. Gerenciamento de recursos materiais: o papel da enfermeira de unidade de terapia intensiva. Rev Rene, 2009 [cited 2018 Feb];10(4):19-27. Available from: http://periodicos.ufc.br/rene/article/view/ 4842/3572

7. Chiavenato I. Gestão de pessoas: o novo papel dos recursos humanos nas organizações. 4. ed. Barueri: Manole; 2014.

8. Bogo PC, Bernardino E, Castilho V, Cruz EDA. The nurse in the management of materials in teaching hospitals. Rev Esc Enferm USP. 2015:49(4):632-9. doi: https://doi.org/10.1590/50080-623420150000400014

9. Fernandes $\mathrm{JC}$, Cordeiro BC. 0 gerenciamento de unidades básicas de saúde no olhar dos enfermeiros gerentes. Rev Enferm UFPE on line. 2018 [cited 2019 May 3];12(1):194-202. Available from: https://periodicos.ufpe.br/revistas/ revistaenfermagem/article/viewFile/23311/25979

10. Minayo, MCS. 0 desafio do conhecimento: pesquisa qualitativa em saúde. 14. ed. São Paulo: Hucitec; 2014.

11. Ministério da Saúde (BR). Portaria no 2.436, de 21 de setembro de 2017. Aprova a Política Nacional de Atenção Básica, estabelecendo a revisão de diretrizes para a organização da Atenção Básica, no âmbito do Sistema Único de Saúde (SUS) Brasilia, DF: Ministeŕrio da Saúde; 2017 [cited 2019 Apr 8]. Available from: http:// bvsms.saude.gov.br/bvs/saudelegis/gm/2017/prt2436_22_09_2017.html

12. Minayo MCS. Amostragem e saturação em pesquisa qualitativa: consensos e controvérsias. Rev Pesq Qualitat. 2017 [cited 2017 Jun 06];5(7):1-12. Available from: https://editora.sepq.org.br/index.php/rpq/article/view/82/59 
13. Alvarenga EC, Oliveira PTR, Pinheiro HHC, Carneiro VCCB. Condições de trabalho de equipes de saúde da família do Pará. Rev NUFEN. 2018 [cited 2019 Apr 30];10(1):58-72. Available from: http://pepsic.bvsalud.org/scielo. php?script=sci_arttext\&pid=\$2175-25912018000100005

14. Oliveira MAM, Navazava T, Andrade WA, Formigoni A. Gerenciamento de estoques em ambiente hospitalar: estudo de caso em um ambulatório público infantil. Rev Exacta-EP. 2016;14(4):527-35. doi: https://doi.org/10.5585/ ExactaEP.v14n4.6089

15. Organização Pan-Americana da Saúde (US). Ampliação do papel dos enfermeiros na atenção primária à saúde. Washington, DC: OPAS; 2018 [cited 2019 Apr 10]. Available from: http://iris.paho.org/ xmlui/bitstream/handle/123456789/34960/9789275720035_por. pdf?sequence $=6 \&$ isAllowed $=y$

16. Acioli S, Kebian LVA, Faria MGA, Ferraccioli P, Correa VAF. Práticas de cuidado: 0 papel do enfermeiro na atenção básica. Rev Enferm UERJ. 2014;22(5):637-42. doi: https://doi.org/10.12957/reuerj.2014.12338
17. Garcia AB, Müller PV, Paz PO, Duarte ERM, Kaiser DE. Perception of users on selfcare of lower leg ulcers. Rev Gaúcha Enferm. 2018;39:e2017-0095. doi: https:// doi.org/10.1590/1983-1447.2018.2017-0095

18. Nunes LO, Castanheira ERL, Dias A, Zarili TFT, Sanine RR, Mendonça CS, et al. Importância do gerenciamento local para uma atenção primária à saúde nos moldes de Alma-Ata. Rev Panam Salud Publica. 2018;42:e175. doi: https://doi. org/10.26633/RPSP.2018.175

19. Gomes, LB, Barbosa MG, Ferla AA, organizadores. A educação permanente em saúde e as redes colaborativas: conexões para a produção de saberes e práticas. Porto Alegre: Rede UNIDA, 2016 [citado 2018 Mar 14]. Available from: http:// historico.redeunida.org.br/editora/biblioteca-digital/serie-atencao-basicae-educacao-na-saude/a-educacao-permanente-em-saude-e-as-redescolaborativas-conexoes-para-a-producao-de-saberes-e-praticas-epub

20. Farah BF, Dutra HS, Sanhudo NF, Costa LM. Percepção de enfermeiros supervisores sobre liderança na atenção primária. Rev Cuid. 2017;8(2):1638-55. doi: https://doi.org/10.15649/cuidarte.v8i2.398

\section{- Corresponding author:}

Dagmar Elaine Kaiser

E-mail: dagmar.kaiser@ufrgs.br

\section{Editor-in-chief:}

Maria da Graça Oliveira Crossetti 